\title{
Intellectual disability in higher education: Self-perceived training needs of university teachers
}

\author{
Miguel Corbía ${ }^{\mathrm{a}}$,Monica Tombolato ${ }^{\mathrm{b}}$, Lidia Bueno-Sánchez, \\ Katrien Hermans ${ }^{\mathrm{d}}$, Antonella Valenti ${ }^{\mathrm{e}}$, Jorge Garcés-Ferrer ${ }^{\mathrm{c}}$, \\ Alessandra M. Straniero ${ }^{\mathrm{e}}$, Branislav B. Brojčin ${ }^{\mathrm{f}}$, Cristina Mesquitag, \\ Evangelina Bonifácio ${ }^{\mathrm{h}}$, Berta Martini ${ }^{\mathrm{b}}$, Sonia Rodríguez-Cano ${ }^{\mathrm{a}}$, \\ Michelle Milants $^{\mathrm{d}}$, Nenad P. Glumbić ${ }^{\mathrm{f}}$ \\ ${ }^{a}$ University of Burgos - Faculty of Education, Burgos, Spain \\ ${ }^{b}$ University of Urbino - Department of Humanistic Studies, Urbino, Italy \\ ${ }^{c}$ University of Valencia - Polibienestar Research Institute, Valencia, Spain \\ ${ }^{d}$ University Colleges Leuven-Limburg (Research \& Expertise), Lueven, Belgium \\ ${ }^{e}$ University of Calabria - Department of Mathematics and Computer Science, Rende, Italy \\ ${ }^{f}$ University of Belgrade - Faculty of Special Education and Rehabilitation, Belgrade, Serbia \\ ${ }^{g}$ Polytechnic Institute of Braganza - Research Center on Basic Education, Braganza, Portugal \\ ${ }^{h}$ University of Salamanca, GIR Helmantica Paidea, Salamanca, Spain
}

Introduction. The inclusion of students with disabilities in higher education is a fundamental right recognised by the legal system since its recognition in the United Nations Convention on the Rights of Persons with Disabilities. However, the measures adopted by European countries to promote their incorporation are not always accompanied by parallel training actions that provide university professors with the necessary knowledge to incorporate people with intellectual disabilities into the classroom with the same guarantees and opportunities as people without intellectual disabilities. Objective. This paper aims to provide specific data on the self-perceived training needs of university teaching staff and thus lay the foundations for a specific training programme. Methods. A cross-sectional study was carried out by means of a survey designed to collect the teachers' perceptions of their own competences and the effectiveness of their knowledge, as well as the importance they attached to some aspects of intellectual disability. The survey was administered to teachers in Serbia, the Netherlands, Portugal, Italy and Spain, with a total sample of 1009 teachers. Results. The results obtained showed that the perception of self-perceived competence in educational skills is dependent on three main factors: previous specific training, teaching experience with people with intellectual disabilities and own personal experiences. Conclusion. The present study demonstrated

Correspondence: Lidia Bueno-Sánchez, lidia.bueno@uv.es

Note. This paper is result of the Erasmus + project "Training university teachers for the inclusion of people with intellectual disabilities" 2019-1-ES01-KA203-065823 
the concern and need of the teaching staff to obtain specific training on people with intellectual disabilities in higher education.

Keywords: higher education, people with intellectual disabilities, teacher training

\section{Introduction}

As established by the United Nations Convention on the Rights of Persons with Disabilities (UN, 2006), the right to education at all levels, including the access to the general tertiary education, is recognized as a fundamental human right, without discrimination and on an equal basis with other members of society. The possibility for people with intellectual disabilities (ID) to attend post-secondary education (PSE) and higher education (HE) courses (i.e., all opportunities after secondary or high school education) is becoming the new challenge for an educational system that can be defined as truly inclusive.

Moreover, combating exclusion is fundamental for the development of the economy (Madaus et al., 2014). People with disabilities who have the opportunity to study at university (Spassiani et al., 2017) increase self-esteem and the opportunities for work and personal growth (Stefánsdóttir \& Björnsdóttir, 2015; Weinkauf, 2002), they feel more self-confident and independent (Wilson et al., 2012), they have more job opportunities (Stefánsdóttir \& Björnsdóttir, 2015). Finally, but not less importantly, the ethical aspect of inclusion is particularly important when referring to people with ID, who deserve to cultivate and fulfil their desires, avoiding the risk of vulnerability associated with segregation (Uditsky \& Hughson, 2012). In this perspective, the discourse around a good quality of life is also inserted, which is associated with the opportunity to have an active role in the society (Schalock \& Verdugo, 2014).

Attitudes and low expectations are among the most significant barriers faced by people with ID in PSE (Hart et al., 2006; Zhang et al., 2010). Therefore, it is somewhat unexpected that studies on the attitudes of university teachers towards the PSE of students with ID are very scarce.

Gibbons et al. (2015) examined the attitudes of 152 teachers of one university towards students with ID and students with autism spectrum disorder (ASD). Teachers had generally positive attitudes towards the inclusion of these individuals in university courses. Three-quarters of them felt that people with ID and people with ASD should be provided with opportunities to study at university and supported the idea of a HE program for these people. About $65 \%$ of them agreed that adapting the teaching style of teachers to enable equal learning opportunities for all students, including those with disabilities, would have positive effects. However, slightly less than half of the teachers thought that other students would feel uncomfortable because of the presence of students with ID and students with ASD in regular courses, as well as that the presence of these students would interfere with routine activities in a class. In addition, a 
quarter of them believe that they should devote more teaching time to students with ID and students with ASD than to other students.

Graves et al. (2020) examined the attitudes of university teachers towards students with ID and/or developmental disability (IDD), especially with regard to their placement in classrooms. They find that support for The Office of Student Disability is the most important factor determining a teacher's selfconfidence when it comes to working with students who have IDD. The second most important factor is the motivation of students with IDD. Previous teaching experience with students with IDD has been an important but not crucial factor in teachers' willingness to accept these individuals in their classes. The comfort felt by teachers in working with a person with IDD was a stronger predictor than years of teaching students with IDD. Teachers had negative attitudes towards the training offered by universities regarding the treatment of students with disabilities, considering it ineffective and irrelevant. It is unclear whether this is a perceived lack of quality or a lack of use of training organized by universities.

Fekete (2013) found that university teachers are somewhat willing to accept students with ID, but analysis of qualitative data suggests that they believe that most of these individuals lack the skills needed to succeed at the university level, so that their involvement could be successful only in introductory classes, that they would have difficulty communicating with teachers and colleagues, that people with significant disabilities would not be able to cope at all in class, and that people with significant disabilities would disturb other students and demand too much attention. However, some respondents felt that students with ID would benefit from participating in college classes and that the inclusion of students with disabilities should be considered on a case-by-case basis.

All these studies were conducted in the United States. Research in Europe on the topic of inclusion of students with ID in university contexts is not very developed. For example, Italy, which has a very advanced legislative framework in terms of inclusion of students with disabilities, both at school and university, and of protection of the right to study, does not have specific measures dedicated to university students with ID, nor does it provide training courses for university teachers on ID, and the research around this problem is not particularly developed. In addition, there is a lack of data collection throughout Europe concerning the number of students with IDs who have undertaken a PSE or HE paths and this does not favour the design of inclusion policies.

The University of Iceland has prepared a professional degree in inclusive settings for students with ID. Based on qualitative research carried out in 20092013 on 39 graduates with ID of the University of Iceland and 14 teachers who have taught inclusive university courses, it can be seen that, despite some reservations, there seems to be a common agreement on the fact that this initiative constitutes an important part of improving access for people with ID to both education and society (Björnsdóttir, 2017; Stefánsdóttir \& Björnsdóttir, 
2015). In Ireland, at Maynooth University, through the Inclusive Learning Initiative (ILI), students with ID were able to enrol at the university and obtain a Certificate of Individual Learning (McCoshan, 2017). In Spain, the Promontory Program (UAM-PRODIS) and the UAM-Prodis Patronage Chair program have allowed some young people with ID to enter the University, showing how the inclusion of people with ID is possible and desirable (Izuzquiza Gasset \& Rodríguez Herrero, 2016; Judge \& Izuzquiza Gasset, 2015; Rodríguez Herrero et al., 2020).

Given that only initial steps in the PSE of the students with ID have been taken in Europe, the objective of this research was to determine formative needs of the university teachers in the selected European countries with different tradition and practices of inclusive education.

\section{Hypotheses}

H1: The importance of transversal training, inclusive methodologies and didactics, specific training and satisfaction with one's own skills and personal training will not be different depending on the educational level.

H2: People who have had previous contact with people with ID will score more highly on the importance of transversal training, inclusive methodologies and didactics, specific training and satisfaction with one's own skills and personal training.

H3: People who have received specific training to teach people with ID will score higher on the importance of transversal training, inclusive methodologies and didactics, specific training and satisfaction with one's own skills and personal training.

H4: People who have previously taught people with ID will score higher on the importance of transversal training, inclusive methodologies and didactics, specific training and satisfaction with one's own skills and personal training.

H5: People who consider training in intellectual disability to be important will score higher on the importance of transversal training, inclusive methodologies and didactics, specific training and satisfaction with one's skills and personal training.

H6: People who consider it necessary to provide access to university for people with ID through minor assistance will score higher on the importance of transversal training, inclusive methodologies and didactics, specific training and satisfaction with one's own skills and personal training.

H7: People who consider it useful to design specific studies for people with ID will score higher on the importance of transversal training, inclusive methodologies and didactics, specific training and satisfaction with one's own skills and personal training. 


\section{Method}

\section{Participants}

The sample was composed of 1009 university teachers (59.7\% women) who work in different countries. Specifically, 31.4\% (317) work in Portugal, 23.2\% (234) in Italy, 16.8\% (170) in Spain, 15.9\% (160) in Serbia and 12.7\% (128) in Belgium. The average age of the participants was 46.8 years $(S D=9.86)$, ranging from 21 to 73 . Regarding their degree, $48.1 \%$ (485) were PhDs, $18.7 \%$ (189) had a Master's degree, and $8.8 \%$ (89) were graduates. The average number of years spent teaching at the university was $15.63(S D=10.11)$, ranging from $1(4.6 \%)$ to $47(0.1 \%)$, with mode being $20(9.1 \%)$.

\section{Measures}

The instrument consisted of a questionnaire ad hoc on perceptions about the importance of different aspects of education for people with intellectual disability, and about the educational skills self-competence perception. The first version of the questionnaire was in Spanish and validated by five experts who reformulated some descriptions to enhance clarity. The final version was translated and validated with two native experts to Serbian, Dutch, Portuguese and Italian, and it was composed for the next sections: informed consent and explanation; 16 items about demographic data; eight items about cross-training formation; 14 items about inclusive methodologies and didactics; eight items about specific formation; seven items about educational skills self-competence perception. All quantitative items were disposed with a Likert scale from 1 (minor value of accordance or satisfaction) to 5 (maximum value of accordance or satisfaction).

\section{Design and procedure}

We used a quasi-experimental cross-sectional design to administer the questionnaires by controlling as many strange variables as possible. To this end, an action protocol was developed that included solutions to the most common problems. The researcher in charge of distributing the questionnaire in each country was also trained to know how to proceed according to the circumstances. This guaranteed the internal validity of the study. The questionnaire was provided in paper or on-line to widespread the sample. The required completion time was about 10 minutes, and the whole procedure guaranteed the anonymity of the participants.

\section{Data analysis}

All analyses were conducted with IBM's SPSS 25.0, and the level of significance was set at $p \leq .05$. First, descriptive analyses were performed for the study variables. Second, a series of ANOVAs were conducted to test the study's hypotheses. 


\section{Results}

Four one-factor ANOVAs were carried out to contrast hypothesis 1. As can be seen in Table 1, statistically significant differences were obtained only in satisfaction with one's personal skills and personal training. According to Bonferroni's Post-hoc comparisons, graduates were more satisfied than people with a Master's degree $(p=.008)$. No differences were found between the other groups.

\section{Table 1}

ANOVA with educational level as independent variable

\begin{tabular}{|c|c|c|c|c|c|c|c|c|}
\hline \multirow{2}{*}{ Variables } & \multicolumn{2}{|c|}{$\mathrm{PhD}$} & \multicolumn{2}{|c|}{ Master } & \multicolumn{2}{|c|}{ Graduated } & \multirow{2}{*}{$F$} & \multirow{2}{*}{$p$} \\
\hline & $M$ & $S D$ & $M$ & $S D$ & $M$ & $S D$ & & \\
\hline Importance of transversal training & 4.11 & 0.89 & 4.02 & 0.85 & 3.89 & 1.01 & 2.41 & .091 \\
\hline $\begin{array}{l}\text { Importance of inclusive didactics and } \\
\text { methodologies }\end{array}$ & 3.99 & 0.83 & 3.88 & 0.85 & 3.82 & 0.98 & 2.40 & .091 \\
\hline Importance of specific training & 4.07 & 0.86 & 4.02 & 0.88 & 3.94 & 0.97 & 0.91 & .403 \\
\hline $\begin{array}{l}\text { Satisfaction with one's own skills and } \\
\text { personal training }\end{array}$ & 2.58 & 1.08 & 2.42 & 1.01 & 2.83 & 1.08 & 4.56 & .011 \\
\hline
\end{tabular}

Four one-factor ANOVAs were carried out to contrast hypothesis 2 . As can be seen in Table 2, statistically significant differences were obtained in importance of transversal training, importance of inclusive didactics and methodologies and in satisfaction with one's personal skills and personal training. Those who had been in contact with people with disabilities scored higher on all these variables.

\section{Table 2}

ANOVA with contact with disabled people as independent variable

\begin{tabular}{|c|c|c|c|c|c|c|}
\hline \multirow{2}{*}{ Variables } & \multicolumn{2}{|c|}{ Yes } & \multicolumn{2}{|c|}{ No } & \multirow{2}{*}{$F$} & \multirow{2}{*}{$p$} \\
\hline & $M$ & $S D$ & $M$ & $S D$ & & \\
\hline Importance of transversal training & 4.11 & 0.86 & 3.98 & 0.91 & 4.32 & .038 \\
\hline $\begin{array}{l}\text { Importance of inclusive didactics and } \\
\text { methodologies }\end{array}$ & 3.99 & 0.88 & 3.83 & .87 & 8.16 & .004 \\
\hline Importance of specific training & 4.06 & 0.84 & 4 & 0.84 & 1.14 & .286 \\
\hline $\begin{array}{l}\text { Satisfaction with one's own skills and } \\
\text { personal training }\end{array}$ & 2.89 & 1.04 & 2.11 & 0.87 & 154.28 & $<.001$ \\
\hline
\end{tabular}


Four one-factor ANOVAs were carried out to contrast hypothesis 3. As can be seen in Table 3, statistically significant differences were obtained in all the variables. Those who had received specific training to teach people with ID scored higher.

\section{Table 3}

ANOVA with specific training for teaching people with ID as independent variable

\begin{tabular}{lccccccc}
\hline & \multicolumn{3}{c}{ Yes } & \multicolumn{2}{c}{ No } & & \\
\cline { 2 - 5 } Variables & $M$ & $S D$ & $M$ & $S D$ & & $p$ \\
\hline $\begin{array}{l}\text { Importance of transversal training } \\
\begin{array}{l}\text { Importance of inclusive didactics and } \\
\text { methodologies }\end{array}\end{array}$ & 4.21 & 0.83 & 4.02 & 0.89 & 7.27 & .007 \\
$\begin{array}{l}\text { Importance of specific training } \\
\begin{array}{l}\text { Satisfaction with one's own skills and } \\
\text { personal training }\end{array}\end{array}$ & 4.17 & 0.76 & 3.87 & 0.84 & 17.5 & $<.001$ \\
\hline
\end{tabular}

Four one-factor ANOVAs were carried out to contrast hypothesis 4. As can be seen in Table 4, statistically significant differences were obtained only in satisfaction with one's personal skills and personal training. Those who had previously taught people with ID scored higher.

\section{Table 4}

ANOVA with teaching of students with ID as independent variable

\begin{tabular}{|c|c|c|c|c|c|c|}
\hline \multirow{2}{*}{ Variables } & \multicolumn{2}{|c|}{ Yes } & \multicolumn{2}{|c|}{ No } & \multirow{2}{*}{$F$} & \multirow{2}{*}{$p$} \\
\hline & $M$ & $S D$ & $M$ & $S D$ & & \\
\hline Importance of transversal training & 4.01 & 0.87 & 4.04 & 0.89 & 0.32 & .569 \\
\hline $\begin{array}{l}\text { Importance of inclusive didactics and } \\
\text { methodologies }\end{array}$ & 3.96 & 0.81 & 3.89 & 0.86 & 1.97 & .160 \\
\hline Importance of specific training & 4.03 & 0.83 & 4.04 & 0.85 & 0.05 & .815 \\
\hline $\begin{array}{l}\text { Satisfaction with one's own skills and } \\
\text { personal training }\end{array}$ & 3.06 & 1.06 & 2.17 & 0.84 & 215.98 & $<.001$ \\
\hline
\end{tabular}

Four one-factor ANOVAs were carried out to contrast hypothesis 5. As can be seen in Table 5, statistically significant differences were obtained in all the variables. Those who consider training in intellectual disability to be important scored higher. 


\section{Table 5}

ANOVA with consider training in ID important as independent variable

\begin{tabular}{|c|c|c|c|c|c|c|}
\hline \multirow{2}{*}{ Variables } & \multicolumn{2}{|c|}{ Yes } & \multicolumn{2}{|c|}{ No } & \multirow{2}{*}{$F$} & \multirow{2}{*}{$p$} \\
\hline & $M$ & $S D$ & $M$ & $S D$ & & \\
\hline Importance of transversal training & 4.15 & 0.81 & 3.54 & 1.12 & 59.21 & $<.001$ \\
\hline $\begin{array}{l}\text { Importance of inclusive didactics and } \\
\text { methodologies }\end{array}$ & 4.04 & 0.74 & 3.27 & 1.09 & 111.24 & $<.001$ \\
\hline Importance of specific training & 4.12 & 0.76 & 3.51 & 1.14 & 68.56 & $<.001$ \\
\hline $\begin{array}{l}\text { Satisfaction with one's own skills and } \\
\text { personal training }\end{array}$ & 2.74 & 1.03 & 1.81 & 0.81 & 104.14 & $<.001$ \\
\hline
\end{tabular}

Four one-factor ANOVAs were carried out to contrast hypothesis 6 . As can be seen in Table 6 , statistically significant differences were obtained in all the variables. Those who consider it necessary to provide access to university for people with ID through minor assistance scored higher.

\section{Table 6}

ANOVA with providing access to university for people with ID through minor assistance as independent variable

\begin{tabular}{|c|c|c|c|c|c|c|}
\hline \multirow{2}{*}{ Variables } & \multicolumn{2}{|c|}{ Yes } & \multicolumn{2}{|c|}{ No } & \multirow{2}{*}{$F$} & \multirow{2}{*}{$p$} \\
\hline & $M$ & $S D$ & $M$ & $S D$ & & \\
\hline Importance of transversal training & 4.13 & 0.82 & 3.75 & 1.06 & 27.59 & $<.001$ \\
\hline $\begin{array}{l}\text { Importance of inclusive didactics and } \\
\text { methodologies }\end{array}$ & 4.01 & 0.75 & 3.52 & 1.05 & 55.60 & $<.001$ \\
\hline Importance of specific training & 4.1 & 0.75 & 3.72 & 1.14 & 31.98 & $<.001$ \\
\hline $\begin{array}{l}\text { Satisfaction with one's own skills and } \\
\text { personal training }\end{array}$ & 2.71 & 1.02 & 2.04 & 0.99 & 62.63 & $<.001$ \\
\hline
\end{tabular}

Finally, four one-factor ANOVAs were carried out to contrast hypothesis 7. As can be seen in Table 7, statistically significant differences were also obtained in all the variables. Those who consider it useful to design specific studies for people with ID scored higher. 
Table 7

ANOVA with usefulness of designing specific studies for people with ID as independent variable

\begin{tabular}{|c|c|c|c|c|c|c|}
\hline \multirow{2}{*}{ Variables } & \multicolumn{2}{|c|}{ Yes } & \multicolumn{2}{|c|}{ No } & \multirow{2}{*}{$F$} & \multirow{2}{*}{$p$} \\
\hline & M & $S D$ & $M$ & $S D$ & & \\
\hline Importance of transversal training & 4.16 & 0.83 & 3.82 & 0.94 & 32.51 & $<.001$ \\
\hline $\begin{array}{l}\text { Importance of inclusive didactics } \\
\text { and methodologies }\end{array}$ & 4.06 & 0.76 & 3.61 & 0.93 & 63.39 & $<.001$ \\
\hline Importance of specific training & 4.14 & 0.77 & 3.77 & 0.95 & 42.01 & $<.001$ \\
\hline $\begin{array}{l}\text { Satisfaction with one's own skills } \\
\text { and personal training }\end{array}$ & 2.68 & 1.06 & 2.37 & 1.01 & 18.43 & $<.001$ \\
\hline
\end{tabular}

\section{Discussion}

In the pursuit of inclusive HE, one specific group of students, namely those with ID, continues to struggle with accessing and participating in HE. This is apparent in the fact that few studies exist on the inclusion of students with ID in HE. In order to create an inclusive HE learning environment where students with ID can also participate, it's important to get a clear view on the training needs from university teachers (Sánchez-Fuentes \& Martín-Almaraz, 2019).

Regarding the educational level, a significant difference exists between people with a graduate diploma and those with a master's or PhD degree related to the satisfaction with one's own skills and training (Table 1). This can possibly be explained by the fact that within the Bachelor-Master structure of the Bologna Declaration (Van der Wende, 2000), a graduate programme often consists of practical experience and learning by doing while a master's and $\mathrm{PhD}$ programme rarely include information and skills, related to inclusion. The fact that more practical experiences are gained within such courses may also lead to a higher sense of self-efficacy, which is consistent with other studies (Ahmmed et al., 2012; Hsien et al., 2009). Next, our findings indicated that respondents who had been in contact with people with ID before, scored higher on all these variables, except on the importance of specific training content (Table 2). Those who had received specific training to teach people with ID also scored higher on all variables (Table 3). The common denominator of these findings is previous 'experience'. Experience with people with disabilities and having received proper teacher training which leads to a greater sense of selfefficacy in teachers (Hsien et al., 2009; Murray et al., 2011) in this study is possibly reflected in greater satisfaction with one's own knowledge and skills. In addition, experience also has a positive influence on attitudes towards 
inclusion, which is possibly reflected in higher scores indicating the importance of providing university teachers with the necessary training and skills.

Regarding the latter, previous experience with teaching students with ID also provides a different perception in satisfaction with one's skills and personal training (Table 4). In fact, teachers with previous experience reveal more satisfaction than those without it, probably because they already demystified some aspects of the teaching-learning process. Teachers without previous experience may be a little anxious about the unknown. This is in line with the study of Mesquita et al. (2014), that aims to understand the perceptions and expectations of teachers in relation to new publics in HE, according to which teachers with higher academic degree recognize that further pedagogical training would be beneficial to improve their pedagogical skills and their interaction with this type of students.

In this context, teachers were also asked about the importance of training in intellectual disability (Table 5). Teachers who consider that it is important to have this kind of training also believe that transversal training, inclusive didactics and methodologies and specific training are also important. However, strangely, they are more satisfied with their own skills and personal training.

Over the years there has been a debate about whether people with ID should be able to have access to HE. Nowadays, with life-long learning and the access of different profiles to university, such as older than 23 years of age or others, this seems to be consensual, at least from the institutions and policies perspective. From the teachers' point of view, people who agree with providing access to university for people with ID through minor assistance also consider that transversal training, inclusive didactics and methodologies and specific training are important (Table 6). As before, they are also more satisfied with their own skills and personal training. The same thing happens with the teachers that are favourable regarding the usefulness of designing specific studies for people with ID (Table 7). They consider that transversal training, inclusive didactics and methodologies and specific training are important. These findings are in accordance with the Fekete (2013) study which found that university teachers were willing to accept students with ID to some extent, but that there would be more educational benefits if they were integrated in specific classes.

\section{Limitations}

This current study provides us with some insights in the training needs of university teachers, related to teaching students with ID. However, a first limitation lies within the concept of ID, which usually occurs with this term and inclusion as well. In this survey there was no clear definition given about what was meant by ID. This may have resulted in different respondents filling in the questionnaire with a different interpretation of the concept of ID. Describing 
ID should be done in follow-up research, using the universal ICF framework (WHO, 2001).

Second, a total of 1009 responses were received. Although this is a high response in absolute numbers, caution is needed when drawing conclusions for all university teachers in these specific countries. With responses from these different countries, this is a rather diverse sample that gives a first indication of the current teacher needs related to students with ID in HE. However, we must take in consideration that possible differences exist between these countries in terms of legislations on inclusive education and the extent to which HE is really inclusive.

The study would benefit if respondents could reveal not only their opinion about their skills and formative needs, but also about their beliefs and stereotypes about people with ID.

\section{Recommendations}

The current study provides a first insight into the formative needs of teachers in case they have to teach people with ID. With this knowledge and insights, the next step can be taken in creating a truly inclusive learning environment, more precisely providing university teachers with the necessary knowledge and skills, as indicated in this survey.

In order to provide university teachers with the necessary knowledge and skills, a training programme can be designed. When designing this training, it is highly important to think about the format of this training. After all, research has already shown that it is important to make sure there are enough active learning elements such as workshops, because they lead to better results and attitudes, compared to (passively) reading information about the topic (Murray et al., 2011). Secondly, it is important to make sure that there are sufficient opportunities for participants to engage in activities and contacts with students with ID. These multiple contacts will have a positive influence on the attitudes of participants, based on the idea of the contact hypothesis (MacMillan et al., 2014). Thirdly, it is important that participants of the programme have sufficient possibilities to exchange knowledge and experiences with each other. In fact, it is even recommended that participants from different educational institutions and countries exchange good practices with each other on this topic.

By designing such training programmes, we can start influencing the attitudes of university professors towards students with ID in HE. This is important as it is an essential part of an inclusive learning environment as proposed by Booth and Ainscow (2002). A truly inclusive learning environment can only be obtained if an inclusive culture is present with positive attitudes towards students with ID, where inclusive practices are being highlighted and exchanged and lastly, where an inclusive policy with specific guidelines and a framework for this group of students is present. 


\section{Conclusions}

In Europe, there are few research studies on teachers' attitudes about PSE for students with ID. However, the need to provide proper educational pathways for this type of students too is one of the challenges of the 2030 UN Agenda for Sustainable Development (Goal 4).

Within this framework, the research project aims to determine the formative needs of university teachers, related to teaching process for people with ID in the European Countries involved in the project. The first action of the project aimed at investigating the importance that university teachers attribute to different aspects: transversal training, training on didactics and inclusive methodologies, specific training on ID, satisfaction with one's own skills and personal training.

The research hypotheses $(\mathrm{H} 1-\mathrm{H} 7)$ are all confirmed on the basis of the analysis of variance.

In light of the data presented above, we can reasonably conclude that the teachers' prior experience plays a significant role: educational experience (i.e., having received specific training); teaching experience (i.e., having performed teaching activities with students with ID); life experience (i.e., having had contact with people with ID). Previous experiences may affect perceptions of self-efficacy in that they likely increase teachers' awareness of both problems and their own abilities and allow them to gain a positive attitude toward inclusion.

The survey constitutes a first moment of reflection for university teachers on the educational problem of teaching people with ID and on the ways of adapting the educational activities proposed for students to successfully develop their learning.

The results of this study are only the first step towards the identification of the training needs of university teachers and towards the definition of training paths characterised by proper contents and methodologies. The next step of the research is to design a pilot course and to validate it experimentally through its administration to a sample of university teachers. In addition to a wide range of transversal contents aimed at improving the knowledge of ID and of the educational needs related to them, such a training course will also have to include specific insights on methodologies and tools for the adaptation of official curricula and teaching materials to the needs of people with ID.

\section{Acknowledgements}

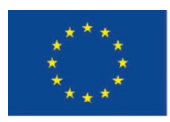

Co-funded by the Erasmus+ Programme of the European Union
The European Commission support for the production of this publication does not constitute an endorsement of the contents which reflects the views only of the authors, and the Commission cannot be held responsible for any use which may be made of the information contained therein. 


\section{References}

Ahmmed, M., Sharma, U., \& Deppeler, J. (2012). Variables affecting teachers' attitudes towards inclusive education in Bangladesh. Journal of Research in Special Educational Needs, 12(3), 132-140. https://doi.org/10.1111/j.1471-3802.2011.012

Björnsdóttir, K. (2017). Belonging to higher education: Inclusive education for students with intellectual disabilities. European Journal of Special Needs Education, 32(1), 125-136. https://doi.org/10.1080/08856257.2016.1254968

Booth, T., \& Ainscow, M. (2002). Index for inclusion: Developing learning and participation in schools. Centre for Studies on Inclusive Education.

Fekete, D. F. (2013). Faculty attitudes toward students with intellectual disabilities in postsecondary educational settings [Doctoral dissertation, Wayne State University]. DigitalCommons@WayneState. https://digitalcommons.wayne.edu/ cgi/viewcontent.cgi?article $=1723 \&$ context $=$ oa_dissertations

Gibbons, M. M., Cihak, D. F., Mynatt, B., \& Wilhoit, B. E. (2015). Faculty and student attitudes toward postsecondary education for students with intellectual disabilities and autism. Journal of Postsecondary Education and Disability, 28(2), 149-162.

Graves, J. A., Mackay, M. M., \& Hunter, W. C. (2020). Factors predicting the successful placement of inclusive post-secondary education students in college courses. $D A D D$ Online, 7(1), 31-43.

Hart, D., Grigal, M., Sax, C., Martinez, D., \& Will, M. (2006). Postsecondary education options for students with intellectual disabilities. Research to Practice Series, 6. https://scholarworks.umb.edu/cgi/viewcontent.cgi?article $=1005 \&$ context $=\mathrm{ici}$ researchtopractice

Hsien, M., Brown, P. M., \& Bortoli, A. (2009). Teacher qualifications and attitudes toward inclusion. Australasian Journal of Special Education, 33(1), 26-41. https://doi.org/10.1375/ajse.33.1.26

Izuzquiza Gasset, D., \& Rodríguez Herrero, P. (2016). Inclusión de personas con discapacidad intelectual en la universidad. Resultados del Programa Promentor (UAM-PRODIS, España). Siglo Cero, 47(4), 27-43. http://dx.doi.org/10.14201/scero20164742743

Judge, S., \& Izuzquiza Gasset, D. (2015). Inclusion in the workforce for students with intellectual disabilities: A case study of a Spanish postsecondary education program. Journal of Postsecondary Education and Disability, 28(1), 121-127.

MacMillan, M., Tarrant, M., Abraham, C., \& Morris, C. (2014). The association between children's contact with people with disabilities and their attitudes towards disability: A systematic review. Developmental Medicine \& Child Neurology, 56(6), 529-546. https://doi.org/10.1111/dmcn.12326

Madaus, J. W., Grigal, M., \& Hughes, C. (2014). Promoting access to postsecondary education for low-income students with disabilities. Career Development and Transition for Exceptional Individuals, 37(1), 50-59. https://doi.org/10.1177/2165143414525037

McCoshan, A. (2017, June 1). Facilitating access to education for adults with intellectual disabilities - why fully inclusive models work. EPALE. https:/epale.ec.europa.eu/ en/blog/facilitating-access-education-adults-intellectual-disabilities-why-fullyinclusive-models-work

Mesquita, C., Lopes, R. P., García, J. Á., \& Rama, M. de la C. del R. (2014). Pedagogical innovation in higher education: Teachers' perceptions. In M. Peris-Ortiz, F. J. Garrigós-Simón, \& I. Gil Pechuán (Eds.), Innovation and teaching technologies: New directions in research, practice and policy (pp. 51-60). Springer International Publishing. https://doi.org/10.1007/978-3-319-04825-3_6 
Murray, C., Lombardi, A., \& Wren, C. T. (2011). The effects of disability-focused training on the attitudes and perceptions of university staff. Remedial and Special Education, 32(4), 290-300. https://doi.org/10.1177/0741932510362188

Rodríguez Herrero, P., Izuzquiza Gasset, D., \& Cabrera Garcia, A. (2020). Inclusive education at a Spanish University: The voice of students with intellectual disability. Disability \& Society. Advance online publication. https://doi.org/10.1080/09687599 .2020 .1745758

Sánchez-Fuentes, S., \& Martín-Almaraz, R. A. (2019). Buenas prácticas en la educación superior basadas en el diseño universal como marco de referencia [Good practices in higher education base don universal design as a frame of reference]. In C. Márquez Vázquez (Ed.), ¿Avanzamos hacia universidades más inclusivas?: De la retórica a los hechos [Are we moving towards more inclusive universities? From rethoric to facts] (pp. 121-137). Dykinson. https://doi.org/10.2307/j.ctvr7f5rq

Spassiani, N. A., Ó Murchadha, N., Clince, M., Biddulph, K., Conradie, P., Costello, F., Cox, L., Daly, E., Daly, O., Middleton, C., McCabe, K., Philips, M., Soraghan, S., \& Tully, K. (2017). Likes, dislikes, supports and barriers: The experience of students with disabilities in university in Ireland. Disability \& Society, 32(6), 892-912. https://doi.org/10.1080/09687599.2017.1320272

Stefánsdóttir, G. V., \& Björnsdóttir, K. (2016). 'I am a college student' postsecondary education for students with intellectual disabilities. Scandinavian Journal of Disability Research, 18(4), 328-342. https://doi.org/10.1080/15017419.2015.1114019

Uditsky, B., \& Hughson, E. (2012). Inclusive postsecondary education - An evidencebased moral imperative. Journal of Policy and Practice in Intellectual Disabilities, 9(4), 298-302. https://doi.org/10.1111/jppi.12005

United Nations (UN). (2006). Convention on the Rights of Persons with Disabilities. UN Department of Economic and Social Affairs, Division for Inclusive Social Development, Programme on Disability.

United Nations (UN). (2018). The 2030 Agenda for sustainable development. UN Department of Economic and Social Affairs.

Van der Wende, M. C. (2000). The Bologna Declaration: Enhancing the transparency and competitiveness of European higher education. Journal of Studies in International Education, 4(2), 3-10. https://doi.org/10.1080/713669277

Weinkauf, T. (2002). College and university? You've got to be kidding: Inclusive postsecondary education for adults with intellectual disabilities. Crossing Boundaries, 1(2), 28-36.

Wilson, H., Bialk, P., Freeze, T. B., Freeze, R., \& Lutfiyya, Z. M. (2012). Heidi's and Philip's stories: Transitions to post-secondary education. British Journal of Learning Disabilities, 40(2), 87-93. https://doi.org/10.1111/j.1468-3156.2012.00746.x

World Health Organization (WHO). (2007). International Classification of Functioning, Disability, and Health: Children \& Youth Version: ICF-CY. World Health Organization.

Zhang, D., Landmark, L., Reber, A., Hsu, H., Kwok, O.-M., \& Benz, M. (2010). University faculty knowledge, beliefs, and practices in providing reasonable accommodations to students with disabilities. Remedial and Special Education, 31(4), 276-286. https://doi.org/10.1177/0741932509338348 


\title{
Intelektualna ometenost u visokom obrazovanju: Samoprocena potreba za obukom univerzitetskih nastavnika
}

\author{
Miguel Corbía, Monica Tombolato ${ }^{\mathrm{b}}$, Lidia Bueno-Sánchez ${ }^{\mathrm{c}}$, \\ Katrien Hermans ${ }^{\mathrm{d}}$, Antonella Valenti ${ }^{\mathrm{e}}$, Jorge Garcés-Ferrerc ${ }^{\mathrm{c}}$, \\ Alessandra M. Straniero ${ }^{\mathrm{e}}$, Branislav B. Brojčin ${ }^{\mathrm{f}}$, Cristina Mesquita ${ }^{\mathrm{g}}$, \\ Evangelina Bonifácio ${ }^{\mathrm{h}}$, Berta Martini ${ }^{\mathrm{b}}$, Sonia Rodríguez-Cano ${ }^{\mathrm{a}}$, \\ Michelle Milants ${ }^{\mathrm{d}}$, Nenad P. Glumbić ${ }^{\mathrm{f}}$ \\ ${ }^{a}$ Univerzitet u Burgosu - Pedagoški fakultet, Burgos, Španija \\ ${ }^{b}$ Univerzitet u Urbinu - Departman za humanističke studije, Urbino, Italija \\ ${ }^{c}$ Univerzitet u Valensiji - Istraživački institut Polibienestar, Valensija, Španija \\ ${ }^{d}$ Univerzitetski koledž Luven-Limburg (Istraživanja i ekspertize), Leuven, Belgija \\ e Univerzitet u Kalabriji - Departman za matematiku i kompjuterske nauke, Rende, Italija \\ ${ }^{f}$ Univerzitet u Beogradu - Fakultet za specijalnu edukaciju i rehabilitaciju, Beograd, Srbija \\ ${ }^{g}$ Politehnički institut u Bragansi - Istraživački centar u oblasti osnovnog obrazovanja, \\ Bragansa, Portugal \\ ${ }^{\text {h} U n i v e r z i t e t ~ u ~ S a l a m a n k i ~-~ I s t r a z ̌ i v a c ̌ k a ~ g r u p a ~ H e l m a n t i c a ~ P a i d e a, ~ S a l a m a n k a, ~ S ̌ p a n i j a ~}$
}

\begin{abstract}
Uvod: Inkluzija studenata sa ometenošću u visokom obrazovanju je fundamentalno pravo koje prepoznaje pravni sistem od usvajanja Konvencije Ujedinjenih nacija o pravima osoba sa ometenošću. Međutim, mere koje su preduzele evropske zemlje u promovisanju tih prava nisu uvek praćene obukama koje bi univerzitetskim nastavnicima obezbedile neophodna znanja za uključivanje osoba sa intelektualnom ometenošću u nastavu sa istim garancijama i mogućnostima koje se nude osobama tipičnog razvoja. Cilj: Cilj ovog istraživanja je da utvrdi potrebe za obukom na osnovu vlastite percepcije univerzitetskog nastavnog osoblja i da na taj način postavi temelje specifičnog programa obuke. Metode: Sprovedeno je transferzalno istraživanje pomoću upitnika kojim su prikupljeni podaci o vlastitoj proceni nastavnika u pogledu kompetencija i efektivnosti njihovog znanja, kao i o značaju koji oni pridaju pojedinim aspektima intelektualne ometenosti. Ispitivanje je izvršeno na uzorku od 1009 nastavnika iz Srbije, Holandije, Portugalije, Italije i Španije. Rezultati: Dobijeni rezultati pokazuju da je samoprocena kompetencija u edukativnim veštinama zavisna od tri glavna činioca: specifičnog treninga u prošlosti, iskustva $u$ podučavanju osoba sa intelektualnom ometenošću i ličnih iskustava, Zaključak: Dobijeni rezultati ukazuju na potrebu za specifičnom obukom nastavnog osoblja u oblasti rada sa osobama sa intelektualnom ometenošću u visokom obrazovanju.
\end{abstract}

Ključne reči: visoko obrazovanje, osobe sa intelektualnom ometenošću, obuka nastavnika

PRIMLJENO: 22.02.2021.

PRIHVAĆENO: 15.05.2021. 